2. Digital currency. Government of Canada. URL: https://www.canada.ca/ en/financial-consumer-agency/services/payment/digital-currency.html (дата звернення: 15.04.2021).

3. BILL C-31. Parliament of Canada. URL: https://www.parl.ca/ DocumentViewer/en/41-2/bill/C-31/third-reading (дата звернення: 15.04.2021).

4. About FINTRAC. Financial Transactions and Reports Analysis Centre of Canada. URL: https://www.fintrac-canafe.gc.ca/intro-eng (дата звернення: 15.04.2021).

5. CSA Staff Notice 46-307 Cryptocurrency Offerings. Ontario Securities Commission. URL: https://www.osc.ca/sites/default/files/pdfs/irps/csa_ 20170824_cryptocurrency-offerings.pdf (дата звернення: 15.04.2021).

6. Transactions Involving Bitcoins. Canadian Tax Litigation. URL: http://www.canadiantaxlitigation.com/wp-content/uploads/2014/01/ 2013-0514701I7.txt?utm_(дата звернення: 15.04.2021).

7. Guide for cryptocurrency users and tax professionals. Government of Canada. URL: https://www.canada.ca/en/revenue-agency/programs/aboutcanada-revenue-agency-cra/compliance/digital-currency/cryptocurrencyguide.html (дата звернення: 15.04.2021).

8. Capital Gains 2020. Canada Revenue Agency. URL: https://www.canada.ca/content/dam/cra-arc/formspubs/pub/t4037/t403720e.pdf (дата звернення: 15.04.2021).

DOI https://doi.org/10.30525/978-9934-26-074-2-32

\title{
ВІДМІННОСТІ АДМІНІСТРАТИВНО-ПРАВОВОГО РЕГУЛЮВАННЯ ОБІГУ ЕЛЕКТРОННИХ КОШТІВ ТА КРИПТОВАЛЮТИ
}

\author{
Ковальчук О. В. \\ аспірантка другого року навчання кафедри \\ адміністративного права і проиесу \\ Національного педагогічного університету імені М. П. Драгоманова \\ м. Київ, Україна
}

На сьогоднішній день, технології розвиваються дуже швидко та держава не завжди вчасно реагує на появу нових технологічних рішень, в Україні така ситуація склалася із обігом криптовалют, адже об'єктивно ринок криптовалют існує, потенційне регулювання такого ринку може принести значні надходження до бюджету але на сьогоднішній 
день в Україні не існує адміністративно-правового регулювання ринку криптовалют. Легалізації такого ринку є нагальною потребою для його учасників, проте небезпечно створювати такий ринок без державного регулювання це може мати значні ризики для фінансової стабільності та економічної безпеки держави.

Електронні гроші та криптовалюти $€$ новими феноменами для юридичної науки, тому дослідження їх сутності, поняття є складним та суперечливим процесом. Поняття «електронні гроші» та «криптовалюта» $\epsilon$ продуктом цифрової економіки. Цифрова економіка базується на інформаційно-комунікаційних та цифрових технологіях, стрімкий розвиток та поширення яких вже сьогодні впливають на традиційну (фізичноаналогову) економіку, трансформуючи ії від такої, що споживає ресурси, до економіки, що створює ресурси. Саме дані $є$ ключовим ресурсом цифрової економіки, вони генеруються та забезпечують електронно-комунікаційну взаємодію завдяки функціонуванню електронно-цифрових пристроїв, засобів та систем [5].

Відповідно до трактування ФАТФ віртуальні та електронні гроші $є$ двома різновидами цифрових грошей. Допускається також використання терміну «цифрові гроші» синонімічно до поняття «віртуальні гроші». В підході FATF (Міжнародна група з протидії відмиванню брудних грошей) визначена важлива характеристика - віднесення цифрових грошей до фіантних, а віртуальних грошей - до не фіантних. Фіатними вважаються гроші, які випускаються центральним банком або іншою установою, визнаються державою законним засобом платежу та не мають власної внутрішньої вартості [2].

Електронні гроші - одиниці вартості, які зберігаються на електронному пристрої, приймаються як засіб платежу іншими особами, ніж особа, яка їх випускає, і є грошовим зобов'язанням цієї особи, що виконується в готівковій або безготівковій формі [1]. Порядок здійснення операцій 3 електронним грошима та максимальна сума електронних грошей на електронному пристрої, що перебуває у розпорядженні користувача, визначаються нормативно-правовими актами Національного банку України. Банк, що має намір здійснювати випуск електронних грошей, зобов'язаний до початку їх випуску узгодити з Національним банком України правила використання електронних грошей, у порядку, встановленому нормативно-правовим актом Національного банку України. Таким чином, регулювання обігу електронних грошей здійснює Національний банк України.

В Україні законодавиць називає криптовалюту віртуальним активом, надання криптовалюті правого статусу це необхідний крок для адміністративно-правового регулювання обігу. Україна зробила перші кроки для функціонування ринку криптовалют в 2019 році прийняла Закон України «Про запобігання та протидію легалізації (відмиванню) 126 
доходів, одержаних злочинним шляхом, фінансуванню тероризму та фінансуванню розповсюдження зброї масового знищення» заклавши поняття віртуальний актив та передбачивши систему фінансового моніторингу криптовалют. Віртуальний актив - цифрове вираження вартості, яким можна торгувати у цифровому форматі або переказувати і яке може використовуватися для платіжних або інвестиційних цілей [4]. В цьому законі визначено Міністерство цифрової трансформації України одним із суб'єктів державного фінансового моніторингу. Державне регулювання і нагляд у сфері запобігання та протидії легалізації (відмиванню) доходів, одержаних злочинним шляхом, фінансуванню тероризму та фінансуванню розповсюдження зброї масового знищення здійснюються Міністерством цифрової трансформації України щодо постачальників послуг, пов'язаних з обігом віртуальних активів.

Україна продовжує роботу із створення умов для адміністративноправового регулювання обігу криптовалют, в Верховній Раді України перебуває проекту Закону України «Про віртуальні активи», прийняття якого:

- сприятиме ефективному розвитку ринку віртуальних активів;

- надасть можливість громадянам та підприємствам на території України, які фактично володіють віртуальними активами, розпоряджатись ними згідно чинного законодавства;

- сприятиме розбудові ринкової інфраструктури віртуальних активів на основі вже наявного світового досвіду, побудові в Україні принципово нових регуляторних механізмів, концепцій та підходів;

- забезпечить можливість надання учасникам ринку віртуальних активів безпечних та якісних послуг;

- створить необхідні передумови для використання органами виконавчої влади України передових технологій, зокрема технологій розподіленого реєстру та його впровадження в роботу державних реєстрів в Україні;

- сприятиме збільшенню інвестицій в економіку України, зокрема, через підвищення довіри внутрішніх та іноземних інвесторів внаслідок запровадження цивілізованих та уніфікованих правил обігу віртуальних активів;

- зменшить частку тіньової економіки, що пов'язана із інвестиціями у віртуальні активи громадян та підприємств в Україні;

- створить необхідні та, в той же час, цілком достатні передумови для прийняття Закону про внесення змін до Податкового кодексу України щодо оподаткування операцій з віртуальними активами, та, відповідно, перспективу отримання додаткових надходжень до Державного бюджету України [3]. 


\title{
Література:
}

1. Про платіжні системи та переказ коштів в Україні: Закон України від 05.04.2001 № 2346-III, Верховна Рада України. Відомості Верховної Ради України (ВВР), 2001, № 29, ст.137

2. Кравчук В. Електронні гроші в Україні. Аналітичний звіт / В. Кравчук, Д. Науменко, А. Глибовець. - К.: Альфа-ПІК, 2012. - 64 с.

3. Пояснювальна записка до проекту Закону України «Про віртуальні активи» від 14.09.2020, Народний депутат України Жмеренецький О.С.

4. Про запобігання та протидію легалізації (відмиванню) доходів, одержаних злочинним шляхом, фінансуванню тероризму та фінансуванню розповсюдження зброї масового знищення: Закон України від 06.12.2020 № 361-IX, Верховна Рада України. Відомості Верховної Ради України (ВВР), 2020. № 25. Ст. 171.

5. Про схвалення Концепції розвитку цифрової економіки та суспільства України на 2018-2020 роки та затвердження плану заходів щодо іiі реалізації: Розпорядження Кабінету Міністрів України від 17.01.2018 № 67-p.

DOI https://doi.org/10.30525/978-9934-26-074-2-33

\section{Е-ВИБОРИ В СУЧАСНОМУ ДЕМОКРАТИЧНОМУ ВРЯДУВАННІ}

\author{
Косілова О. I.
}

кандидат політичних наук, дочент, науковий співробітник

Інституту права

Київського начіонального університету імені Тараса Шевченка

\section{Федірко I. П.}

кандидат філософських наук, доцент, доцент кафедри політології філософського факультету

Київського національного університету імені Тараса Шевченка м. Київ, Україна

Пандемія COVID-19 істотно прискорила розвиток технологій i вплинула на роль цифровізації в цілому світі. 3 розвитком та розповсюдженням Інтернету з'явилися нові інформаційно-комунікаційні техно- 